\title{
Fiscal illusion as an incentive for local government public expenditure efficiency: The influence of community sensitization
}

\section{Paul Onyango-Delewa}

\author{
Department of Accounting and Finance, Faculty of Business and Development Studies, \\ Gulu University, Gulu, Uganda
}

Correspondence authoremail: ponydel2005@gmail.com; ponydel@gu.ac.ug.

\begin{abstract}
Although the effect of public expenditure efficiency on local government fiscal performance is widely-documented, what precisely explains expenditure efficiency remains largely unclear. Nevertheless, past research holds fiscal illusion as the most likely predictor and community sensitization very critical for fiscal illusion-expenditure efficiency formation. We employed fiscal illusion theory to investigate possible fiscal illusion-community sensitization-expenditure efficiency mediation in 16 districts, 6 municipalities, and 160 sub-counties of Uganda's northern region. Over the years, Uganda; an East African country, is applauded for its fiscal federalism proficiency. But presently, its northern region is grappling a 20 -year post-conflict trauma likely to compromise entity spending efficiency. Structural equation modeling results suggest that all the four fiscal illusion constructs: fiscal imbalances, political divide, tax payment bias, and fiscal sabotage, predict changes in expenditure efficiency. However, community sensitization does not mediate the fiscal illusion-expenditure efficiency linkages. Implications for these findings and possible direction for future research are discussed.
\end{abstract}

Keywords: Community sensitization, Expenditure efficiency, Fiscal illusion, Local government

JEL Classification: H31, H71, H72

\section{INTRODUCTION}

Sub-national entities particularly local governments are meant to provide public services of different kinds to their citizens. In developing countries such as those of SubSaharan Africa, common public services at local level include: education, health, road networks, water and sanitation, and cultural and communal support (Afonso \& Fernandes, 2008; Gupta \& Marijn, 2001). The fiscal federalism mandate also requires that the services must be of sustainable, high quality, and cost-effective nature (Gupta \& Marijn, 2001). However, attaining that obligation effectively necessitates pre-determined, properly-managed, and constantly-monitored spending. Mutually, this is what is termed public expenditure efficiency by public administration-related theory, research and practice (Clemens \& Miran, 2012; Gupta \& Marijn, 2001).

As noted by Blair (2000) and most recently Clemens \& Miran (2012), few entities in either the developed or developing world have ever attained acceptable levels of public expenditure efficiency. Hence, it is not clearly understood what precisely explains that problem. Much as resource-constraint, corruption, bureaucracy, tribal differences, and 
partisan politics are frequently cited by related studies (e.g. Afonso \& Fernandes, 2008; Gupta \& Marijn, 2001) as predictors of public expenditure efficiency especially in Africa, the position is not decisive enough.

Guided by fiscal illusion theory (Oates, 1991; Wagner, 1976), several scholars (notably Dollery \& Worthington, 1996; Devas, Delay \& Hubbard, 2001; Dell'Anno \& Mourao, 2012), assert that public expenditure inefficiency is largely a function of fiscal illusion practices. However, other researchers such as Ferrari \& Manzi (2014) and Francis \& Robert (2003) maintain that much as fiscal illusion possibly predicts changes in public expenditure efficiency, that prediction cannot be sustainable without community sensitization.

This study investigates fiscal illusion-public expenditure efficiency connections in selected local governments of Uganda, East Africa. It also examines whether community sensitization actually mediates the fiscal illusion-public expenditure efficiency relationship. For quite a long time, Uganda has been considered a proficient fiscal federalism player in Sub-Saharan Africa (Clemens \& Miran, 2012). Its decentralization system rests on seven political and administrative regions that play host to one city (Kampala), 100 municipalities, 168 districts, and about 1,800 sub-counties. While the regions include: western, south-western, central, north-western, northern, north-eastern, and eastern, the district is the principle local entity in the country (Clemens \& Miran, 2012; Ferrari \& Manzi, 2014).

This paper makes three remarkable contributions to local government public expenditure efficiency literature. First, we introduce; apparently for the first time, a fiscal illusion-community sensitization-public expenditure efficiency model. This empirical innovation opens up opportunity for future scholars to carry out in-depth analysis of the otherwise chronic public expenditure efficiency problem. In practice, this will not only benefit African and other developing nations-based local entities, but also those in the developed world. Specifically, the model emphasizes the likely influence of community sensitization; a factor largely overlooked by past studies (e.g. Gemmell, Morrissey \& Pinar, 2002; Mourao, 2006), in providing a sustainable solution to the expenditure efficiency dilemma.

Second, much as the current research focuses on the operations of local governments in only one country; Uganda, its motives are in no way parochial or narrowminded. Rather it is a survey founded on a strong theoretical set-up (Oates, 1991; Wagner, 1976) and guided by equally a wide literature framework (e.g. Blair, 2000; Congleton, 2001; Ferrari \& Manzi, 2014). In other words, the study's empirical set-up covers a broad range of global fiscal federalism experiences. Such experiences are likely to significantly benefit imminent works. This is in the reality that local entities are not confined to promoting the well-being of local communities alone, but constitute a critical factor in the national macroeconomic-development agenda (Gupta \& Marijn, 2001).

Third, the study also targets entity administrators, employees, political representatives and the local communities. The idea is to draw their attention to the way public funds are expected to be spent and accordingly accounted for especially amidst resource scarcity and budgetary requirement realities. Consistent with evidence in the work of Gemmell, Morrissey and Pinar (2002), stakeholder appreciation and understandability of resource sourcing-expenditure linkages will greatly enhance expenditure efficiency. 


\section{THEORY, LITERATURE AND HYPOTHESES STRUCTURE}

\section{Public expenditure efficiency}

Public expenditure is considered efficient when; given the amount spent, that amount is capable of generating the largest benefit possible for a country's population. However, decentralization policy broadly acknowledges that attaining expenditure efficiency especially at national level is not an easy task (Blair, 2000; Gupta \& Marijn, 2001). This is basically because measuring both costs and benefits associated with public outlay is quite a complex undertaking.

Consistent with the fiscal illusion theory (Oates, 1991; Wagner, 1976), this generally arises from either entity failure to appreciate the implication of government expenditure or local community failure to accurately perceive expenditure outcome. Further, Wagner (1976) relates fiscal illusion to lack of transparency in revenue collection leading to public expenditure misinterpretation and eventually inefficiency.

On that basis, various countries in both the developed and developing world have gone fiscal federalism ideally to achieve public expenditure efficiency (Devas, Delay \& Hubbard, 2001). Under fiscal federalism jurisdiction, expenditure efficiency is considered fairly practical on the grounds of presumed related accountability, responsiveness, governance, and quality service delivery operational dimensions (Afonso \& Fernandes, 2008; Devas, Delay \& Hubbard, 2001).

Essentially, as noted by Clemens and Miran (2012), public expenditure efficiency is feasible even in resource-constrained sub-national entities of developing countries as long as adequate technical commitment abounds. In congruence, related research (e.g. Afonso \& Fernandes, 2008; Blair, 2000) indicates that while technical commitment is pivotal, there must be regulatory compliance in respect to all executed expenditure. Moreover, completion of public service-related projects which signify cost-benefit uniformity is also indicative of public expenditure efficiency especially at local government level (Gupta \& Marijn, 2001).

\section{Technical commitment}

Local entity decision-makers and citizens play a critical role in paving the way public funds are supposed to be expended. This is especially so from public financial resource shortages and budgetary restrictions contexts typical of majority developing economies. As observed by Blair (2000) and Devas, Delay \& Hubbard (2001), in such jurisdictions, public resources must be spent according to sustainability, efficiency, efficacy and economy principles. Supported by published fiscal data (e.g. Gupta \& Marijn, 2001), these principles enhance local community information accessibility relevant for effective monitoring and control of entity administrators activities.

However, attaining that outlay standard requires reliable technical skills, commitment and transparency (Clemens \& Miran, 2012). In Sub-Saharan Africa, local governments are persistently plagued with substantial service delivery and backlog challenges, corruption, and poor budgetary and financial management. This is largely due to administrator-employee technical skills incapacitation (Afonso \& Fernandes, 2008; Clemens \& Miran, 2012).

In Ugandan-based districts, notable administrators include: resident district commissioner (RDC), chief administrative officer (CAO), local council 5 (LC5) chairperson, chief finance officer (CFO), heads of department, and community representatives. The district constitutes the principle and foundational local entity in the country's decentralization structure (Blair, 2000; Gupta \& Marijn, 2001). 
The RDC is directly appointed by the president to coordinate public services, advice the LC5 chairperson on national political and economic matters, and execute any other matters assigned by the president or prescribed by parliament. Practice and research (e.g. Afonso \& Fernandes, 2008; Clemens \& Miran, 2012) have shown that majority RDCs in the country are appointed on political grounds and generally lack public finance technical knowledge and skills.

The CAO; appointed by public service commission at national level, would be technical but their capacity is often compromised by tribalism and partisan politics. Heads of department, employees and community representatives are appointed by the district service commission largely on sectarian, tribal and political considerations (Blair, 2000; Clemens \& Miran, 2012).

Amidst the foregoing personnel appointment inconsistencies and lack of operational autonomy, it explains why various past studies (e.g. Blair, 2000; Congleton, 2001; Dollery \& Worthington, 1996; Mourao, 2006), persistently advocate for local entity autonomy in order to secure community services. Furthermore, and perhaps most terrifyingly, this situation also expounds why some scholars (Afonso \& Fernandes, 2008; Clemens \& Miran, 2012; Dell'Anno \& Mourao, 2012) have for long envisioned reversal towards centralization as the only panacea to the expenditure efficiency problem in Africa.

\section{Regulatory compliance}

When local governments act within the parameters of budgetary and financial management law, they regulate and manage public expenditure under their control effectively. Fiscal illusion theory (Oates, 1991; Wagner, 1976), research (e.g. Blair, 2000; Clemens \& Miran, 2012; Congleton, 2001), and fiscal federalism policy posit that public spending responsibility be preferably executed by authorities closest to the communities.

Given their technical competencies, these entity administrators will execute their expenditure mandates within the law. Besides, Clemens \& Miran (2012) suggest that in resource-strained and corruption-ridden entities such as those of Africa, central governments intervention be limited. For instance, higher authorities should only come in when local spending coordination and discharge is persistently inefficient.

Uganda, Kenya, Nigeria, Ethiopia, and South Africa; to name but a few SubSaharan Africa countries, operate tightly-regulated public expenditure mechanisms (Afonso \& Fernandes, 2008; Dell'Anno \& Mourao, 2012). However, what undermines judicial systems in these countries; notably that of Uganda, is lack of independence in handling particularly fiscal corruption and accountability incidences (Dell'Anno \& Mourao, 2012).

\section{Projects completion}

Globally, public service projects require huge amounts of fiscal and other resources in order to be set-up. Key projects include: education and health facilities, road networks, and water and sanitation amenities. In Africa, the largely rural-based projects are mainly financed by inter-governmental fiscal transfers (grants) and donor aid. Over the years, empirical evidence (Blair, 2000; Ferrari \& Manzi, 2014; Gupta \& Marijn, 2001; Mourao, 2006) highlights community-based projects completion as the most crucial public expenditure efficiency challenge faced by majority local entities in the region.

Although funded by central government-highly monitored conditional grants and donor aid, few projects are satisfactorily completed. Inter alia, the works of Ferrari and Manzi (2014) and Mourao (2006) identify budgetary inconsistency and technical incapacitation as the most salient factors responsible for projects completion 
complications in Sub-Saharan Africa. Moreover, in the case of Ugandan-based projects, Gupta \& Marijn (2001) claim that lack of entity fiscal autonomy and corruption betray completion efforts at local levels.

\section{Fiscal illusion}

For quite a long time, past research (e.g. Dollery \& Worthington, 1996; Devas, Delay \& Hubbard, 2001; Dell'Anno \& Mourao, 2012), has attributed local government failure to attain public expenditure efficiency to fiscal illusion. However, over the years, little significant effort has been taken to carry out an effective empirical investigation of the fiscal illusion-public expenditure efficiency linkages particularly in Africa-based local entities. According to Dollery \& Worthington (1996) and more recently Dell'Anno \& Mourao (2012), fiscal illusion is the prospect that entity costs and benefits may consistently be misconstrued by the local community.

Notably, Dell'Anno \& Mourao (2012) highlight five economics-founded fiscal illusion generic attributes: revenue complexity, revenue elasticity, flypaper effect, renter illusion, and debt illusion. Accordingly, it is the flypaper effect and renter-illusion dimensions that explain the fiscal illusion prediction of public expenditure efficiency in local government (Devas, Delay \& Hubbard, 2001; Dell'Anno \& Mourao, 2012).

The flypaper concept holds that there is often a hypothesized tendency for central government grants; meant to finance local entity programs, to increase public expenditure by more than an equivalent increment in other forms of local revenue (Dell'Anno \& Mourao, 2012; Guziejewska, 2016). Consequently, local administrators and community misperception that grants are gifts leads to expenditure mismanagement and inefficiency. It also makes the local taxpayers underestimate the reality that their tax liability increases correspondingly with those at national level (Dollery \& Worthington, 1996; Guziejewska, 2016).

According to Devas, Delay \& Hubbard (2001), renter-illusion rests on the reality that various local governments in majority fiscal federalism jurisdictions largely rely on property tax. The underlying assumption is that those communities that own property and are thus directly levied, will always correctly estimate public goods and services tax prices (Dollery \& Worthington, 1996; Devas, Delay \& Hubbard, 2001).

However, given the high illiteracy rate and lack of technical capacity among the local populace especially in Sub-Saharan Africa, tax price estimates are rarely accurate. This misconception leads local entity administrators to often mismanage expenditure and breed unnecessary spending inefficiency (Devas, Delay \& Hubbard, 2001; Guziejewska, 2016).

Beneath the fiscal illusion-flypaper effect-renter illusion triangulation, resides four critical factors that recent studies (e.g. Congleton, 2001; Dell'Anno \& Mourao, 2012; Gemmell, Morrissey \& Pinar, 2002; Guziejewska, 2016; Mourao, 2006) claim predict changes in public expenditure efficiency especially in African local entities. These are: fiscal imbalances, political divide, tax payment bias, and fiscal sabotage.

\section{Fiscal imbalances}

At the heart of the fiscal federalism policy lies intergovernmental grants. Grants are meant to finance political, administrative, and economic activities at sub-national level otherwise executed by central government. Fiscal federalism advocates (e.g. Devas, Delay \& Hubbard, 2001; Gemmell, Morrissey \& Pinar, 2002; Mourao, 2006) argue that these fiscal transfers create multi-tiered governmental fiscal equity and equilibrium necessary for generating balanced macroeconomic stability and development. 
However, in more recent empirical work, some scholars; notably Dell'Anno \& Mourao (2012), and Guziejewska (2016) remain highly skeptical about the traditionally and often acclaimed role grants play in particularly local government fiscal machinery. The researchers identified a strikingly similar pattern in decentralized countries of both the developed and developing world: both vertical and horizontal fiscal imbalances created by intergovernmental grants breed free-spending tendencies in majority subnational entities of most countries (Dell'Anno \& Mourao, 2012).

Free-spending; a strong indicator of public expenditure inefficiency, eventually culminates into unsustainable fiscal deficits. Shortly thereafter, the perpetrator local entity calls upon central government to provide special bail-out transfers (supplementary budgets) or otherwise assume the liability (Dell'Anno \& Mourao, 2012).

Accordingly, this implies that fiscal federalism indirectly extends mandate to some local entities to spend unnecessarily but transfer the cost burden to others. Moreover, the unfair fiscal mandate does not only hamper inter-entity competition; but as noted Guziejewska (2016), intergovernmental grants-generated fiscal imbalances significantly distort local revenue-grants linkages.

Consistent with the fiscal illusion theory (Oates, 1991; Wagner, 1976), in weak fiscal federalism jurisdictions such as those of Sub-Saharan Africa, entity administrators take advantage of uncoordinated local revenue-grants setups and related fiscal illusion misperception to overspend. Additionally, it has also been empirically demonstrated (Devas, Delay \& Hubbard, 2001; Mourao, 2006) from the flypaper effect context, that even if grant amounts are increased, they cannot lead to local tax reduction.

In Ethiopia, Nigeria, South Africa, and specifically Uganda, frequent increments in grants levels have instead stimulated more public spending in local governments. Unfortunately, given the country's local entity questionable technical capacities, rampant corruption and rent-seeking practices, public expenditure inefficiency has been the norm (Devas, Delay \& Hubbard, 2001; Guziejewska, 2016; Mourao, 2006). From the foregoing seemingly-endless fiscal imbalances-public expenditure efficiency deliberation, the following hypothesis is therefore proposed:

Hypothesis 1: Fiscal imbalances are positively related to public expenditure efficiency.

\section{Political divide}

Decentralizing political, administrative, and fiscal powers from central government to sub-national entities is basically a political initiative (Mourao, 2006). In fiscal matters, the politics further determines who should play which role in the sub-national budgetary and financial management systems. Furthermore, politics also sets the judicial structure under which various fiscal matters are governed (Devas, Delay \& Hubbard, 2001; Mourao, 2006).

As notes Congleton (2001), local entity leadership often measured by the percentage of council seats held by the ruling political party, has substantial influence on expenditure efficiency. This is particularly the case in autocratic democracies where opposition party views are often sidelined. Besides, some scholars (e.g. Dell'Anno \& Mourao, 2012; Gemmell, Morrissey \& Pinar, 2002; Guziejewska, 2016) posit that the dictatorial approach employed in fiscal spending, heavily distorts the local revenue-grants structure and stimulates fiscal illusion misperception.

In Ugandan and South African-based local jurisdictions; for instance, often compromised democratic checks and balances arising from political divide, continually engender poor service delivery (Devas, Delay \& Hubbard, 2001; Guziejewska, 2016). The preceding insight leads to this hypothesis:

Hypothesis 2: Political divide and public expenditure efficiency are positively related. 


\section{Tax payment bias}

Both Oates (1991) and Wagner (1976); in their fiscal illusion theory propositions, commend decentralization and particularly fiscal federalism as the most ideal instrument of managing differences in local services tastes. Besides, it is a realistic tool that voters can employ to control entity administrators and political representatives' performance effectively (Wagner, 1976). To this end, Oates (1991) relates the performance dimension to a balanced, autonomous, and reliable local tax system. Such a tax performing system is capable of administering various types of taxes, fees, licenses, and charges simultaneously and in the most effective manner.

In practice, however, majority local tax authorities especially in resourceconstrained economies of Sub-Saharan Africa, operate generally-balanced local tax systems but prone to perpetual tax payment bias. Empirical evidence (Congleton, 2001; Devas, Delay \& Hubbard, 2001; Dollery \& Worthington, 1996; Gemmell, Morrissey \& Pinar, 2002) indicates that various local tax authorities in Ethiopia, Ghana, Kenya, Nigeria, Uganda, and South Africa; to name but a few, tend to emphasize property tax administration.

In Uganda, for instance, local governments generate their local revenue from property tax, local service tax, market dues, licenses, and various types of fees, but property tax is most underscored (Dollery \& Worthington, 1996; Gemmell, Morrissey \& Pinar, 2002).

The related policy stand is that that property tax is the only reliable and most effective form of taxation given its administration convenience. Additionally, it is the only form of tax with capacity of providing proper local entity incentives that can easily generate quality services. The services do not only raise community property value but ultimately empower revenue collection capacity (Congleton, 2001; Gemmell, Morrissey \& Pinar, 2002).

However, recent research (e.g. Clemens \& Miran, 2012; Dell'Anno \& Mourao, 2012; Guziejewska, 2016) cautions that reliance on a single tax source breeds taxpayer bias and eventually tax evasion. Tax evasion has traditionally been associated with poor revenue collection, exacerbation of corruption and rent-seeking practices, fiscal transfers over-dependence, budget incrementalism, and inevitably fiscal illusion misperception (Clemens \& Miran, 2012 Guziejewska, 2016). However autonomous a local entity may be, when it operates in such as a fiscal environment, its public expenditure efficiency endeavors must be restrained (Guziejewska, 2016). In sum, the Dell'Anno \& Mourao (2012) perspective that local entities compromise their own public expenditure efficiency drive, may be substantive. We therefore propose that:

Hypothesis 3: Tax payment bias and public expenditure efficiency have a positive relationship.

\section{Fiscal sabotage}

In Sub-Saharan Africa, like other regions of both the developed and developing world, several countries operate fairly properly-decentralized governance and administrative structures (Afonso \& Fernandes, 2008; Gupta \& Marijn, 2001). Indeed countries like Ethiopia, Nigeria, South Africa, and Uganda, have over the years been acclaimed for particularly well-organized fiscal decentralization systems. These systems are largely funded by intergovernmental fiscal transfers and often supported by donor aid (Afonso \& Fernandes, 2008; Clemens \& Miran, 2012).

Some scholars (e.g. Dell'Anno \& Mourao, 2012; Dollery \& Worthington, 1996; Guziejewska, 2016) claim that the fiscal transfers-local revenue bases setup is not only associated with fiscal imbalances, but most importantly, generates fiscal illusion and 
associated expenditure inefficiency. Accordingly, government administrators and political representatives in several local jurisdictions across Africa, consider the fiscal imbalances-fiscal illusion-inevitable expenditure inefficiency triangulation some form of fiscal sabotage (Dell'Anno \& Mourao, 2012; Guziejewska, 2016).

In Uganda, for instance, this fiscal sabotage act has been perceived a deliberate political move designed to frustrate existing local authority fiscal mandates and get opportunity to create more districts (Clemens \& Miran, 2012; Dollery \& Worthington, 1996; Guziejewska, 2016). From less than 40 districts when the country adopted decentralization system in the early 1990s, today Uganda boasts of beyond 140 districts (Guziejewska, 2016).

Consistent with fiscal illusion theory (Oates, 1991; Wagner, 1976), current fiscal federalism research (e.g. Congleton, 2001; Gemmell, Morrissey \& Pinar, 2002; Mourao, 2006) cautions that grantors who take advantage of fiscal illusion misperceptions to destabilize local entity operations, equally undermine their long-term macroeconomic growth-development objective. Moreover, creating unnecessarily large numbers of districts and other local entities can neither promote fiscal federalism, achieve public expenditure efficiency, nor gain local community service popularity.

It simply constitutes political backwardness and lack of fiscal foresight (Clemens \& Miran, 2012; Guziejewska, 2016). Accordingly, the ensuing hypothesis abounds:

Hypothesis 4: Fiscal sabotage and public expenditure efficiency should be positively related.

\section{Community sensitization}

As noted in the introductory remarks of the current research, sub-national entities particularly local governments are meant to provide various kinds of public services to their citizens, the community. Afonso \& Fernandes (2008), but earlier Gupta \& Marijn (2001), identified services such as education, health, road networks, water and sanitation, and cultural and communal support as the most prevalent. This implies that communities must; firstly, be fully aware of the kind of services they require for development purposes, and secondly, the monetary and fiscal cost implications of these services. In cost terms, society must then properly appreciate how that cost is funded (Gupta \& Marijn, 2001; Guziejewska, 2016).

From their community sensitization empirical stand, Ferrari \& Manzi (2014) \& Francis \& Robert (2003) emphasize that local communities in modern fiscal federalism nations; including those of Africa, are expected to understand the four basic local revenue sources. These are local tax, fiscal transfers, donor aid, and loans. Or else, it is the duty of relevant authorities to timely sensitize society on this matter. Furthermore, the community must also be fully-conversant with the public expenditure-service benefit equation (Ferrari \& Manzi, 2014).

Fiscal illusion has for long been empirically identified with public expenditurebenefits community misperception. Given that citizens of majority communities in the developing world particularly those of Africa are largely illiterate, politicians often take advantage of this fiscal knowledge gap to mislead the population (Ferrari \& Manzi, 2014; Mourao, 2006). Moreover, entity administrators working in collaboration with the rentseeking politicians, deliberately mismanage the available fiscal resources since the accountability mechanism is simply too weak (Mourao, 2006).

Some studies (e.g. Dell'Anno \& Mourao, 2012; Gemmell, Morrissey \& Pinar, 2002; Guziejewska, 2016) have also identified Ethiopian, South African, and Ugandan partisan politics and their more or less non-independent judicial systems with community sensitization deficiencies. For instance, Dell'Anno \& Mourao (2012) claim that politics 
and judicial impunity in these countries, significantly betray community sensitization on public expenditure concerns.

Consequently, public expenditure efficiency endeavors in majority of their local entities only exist in theory but practically, they largely remain a fiscal dream (Dell'Anno \& Mourao, 2012).

Therefore, in order to establish the precise position of community sensitizationfiscal illusion-public expenditure efficiency linkages in local government, the following hypothesis was tested:

Hypothesis 5: Community sensitization mediates the relationship between fiscal illusion and public expenditure efficiency.

\section{METHODS}

Fiscal illusion and the local government public expenditure efficiency problem especially in Africa are generally considered extremely complex dimensions (Clemens \& Miran, 2012; Dell'Anno \& Mourao, 2012; Ferrari \& Manzi, 2014). Thus, an investigation that involves establishing fiscal illusion-community sensitization-public expenditure efficiency linkages in such a resource-strained setting requires an equally effective research design (Cheung \& Lau, 2008).

As recommended by various past studies (e.g. Hooper, Coughlan \& Mullen, 2008; Ketchen, Boyd \& Bergh, 2008), this research therefore engaged cross-sectional design given its capacity to generate rich and reliable data. The district, municipality, and subcounty were the study units of analysis while their administrators, employees, and community political representatives were its units of inquiry.

\section{Sample}

Hypotheses proposed in this study were tested using 255 questionnaires administered in 16 districts, 6 municipalities, and 160 sub-counties located in the northern-post conflict region of Uganda. The country's northern region; comprising of both Acholi and Lango sub-regions and a host to a series of public infrastructural projects, was purposively targeted given its perpetual public expenditure efficiency complications (Clemens \& Miran, 2012; Ferrari \& Manzi, 2014).

Sample participants included: 17\% administrators (chief administrative officers, resident district commissioners, town clerks and local council 5 chairpersons), $19 \%$ chief finance officers, $24 \%$ heads of department, $30 \%$ finance operations-related employees, and $10 \%$ community representatives. By means of a stratified sampling method (Cheung \& Lau, 2008; Ketchen, Boyd \& Bergh, 2008), the participants were chosen randomly and purposively based on: position held (from all levels and job classification), period served (well-established and newer staff), and their stations in various localities.

However, due to sampling attrition (Ketchen, Boyd \& Bergh, 2008), only 246 questionnaires (response rate 96\%) were statistically analyzed. The response rate meets the empirical minimum of $65 \%$ for such studies (Dollery \& Worthington, 1996; Hooper, Coughlan \& Mullen, 2008). Participant biographical assessment revealed that $63 \%$ of them are male and the rest female but with mean age bracket of 40 years ( $\mathrm{SD}=1.804)$.

Notably too, $64 \%$ of the respondents were married and $20 \%$ of them single. Majority of them (62\%), are first degree-and-above certificate holders, while $21 \%$ hold diplomas. In terms of period served in various entity capacities, most respondents $(61 \%)$ have occupied their positions for a period between 6 and 10 years.

Consistent with past research related to other parts of Africa (e.g. Gemmell, Morrissey \& Pinar, 2002; Gupta \& Marijn, 2001), the present study suggests that the surveyed local governments engage fairly well-educated personnel. Moreover, they 
operate with a gender-balance focus, targeting manpower of middle age, with family responsibility, and potential to serve for a long time in future (Gemmell, Morrissey \& Pinar, 2002).

\section{Analytical procedures}

In line with previous research (e.g. Cheung \& Lau, 2008; Ketchen, Boyd \& Bergh, 2008), the present study's descriptive and inferential statistics were generated using the Statistical Package for Social Sciences (SPSS) package. Accordingly, its instrument reliability and validity, and variable means, standard deviations, multicollinearity, correlation and prediction (regression) status were established. Cheung \& Lau (2008) and Ketchen, Boyd \& Bergh (2008) suggest that such preliminary statistics are critical for subsequent reliable hypothesis test results.

Proposed hypotheses were tested for both direct and indirect (mediation) effects by means of structural equation analysis (SEM) methodology rooted in the globallyacclaimed (Edwards \& Lambert, 2007; Hooper, Coughlan \& Mullen, 2008; Ketchen, Boyd \& Bergh, 2008) Analysis of Moments Structures (AMOS) software.

In order to effectively verify the direct and mediation properties anticipated in the study hypothetical model, SEM was engaged on the recommended (Hooper, Coughlan \& Mullen, 2008; Ketchen, Boyd \& Bergh, 2008) two-step approach. According to Hooper, Coughlan \& Mullen (2008), the bi-step tactic that engenders a measurement model and a structural model, significantly facilitates study variable-original data consistency verification. While the measurement model supports generation of goodness-of-fit indices required for general hypothesis effects testing, the structural model specially highlights mediation estimation statistics (Cheung \& Lau, 2008; Edwards \& Lambert, 2007).

\section{Measures}

In order to measure the various variable constructs of the study, previous research scales were adopted but modified accordingly. Devas, Delay \& Hubbard (2001) and Edwards \& Lambert (2007) applaud this approach for its effectiveness in measuring social science-related constructs. Thus:

\section{Technical commitment}

The construct technical commitment was assessed by 13 items $(\alpha=0.827)$ developed along the lines in validated scales employed by Blair (2000) and Gupta \& Marijn (2001). Sample item: "This entity employs manpower with relevant technical capacity."

\section{Regulatory compliance}

On the basis of 12 items $(\alpha=0.813)$ closely related to those in the modified scale of Afonso \& Fernandes (2008) research, the attribute regulatory compliance was measured. One of such items included the following: "Current expenditure efficiency regulations favor entity environment."

\section{Projects completion}

The 15 items $(\alpha=0.791)$; sample: "Most infrastructure-related projects in this local government have never been fully completed since initiation", developed along the tailored Clemens \& Miran (2012) scales, was adopted in verifying the concept projects completion.

\section{Fiscal imbalances}

The scales in the empirical work of Congleton (2001) and Mourao (2006) were systematically adjusted to help support the 15 items $(\alpha=0.854)$ that were used in verifying the construct fiscal imbalances of this study. One of such items ran as follows: "This entity is relatively competitive because of fiscal imbalances." 


\section{Political divide}

A modified scale drawn from previous research (Dollery \& Worthington, 1996) was employed by the current study to investigate the attribute political divide. The item: "[ $\ldots]$ fiscal expenditure issues are handled along political lines" was one of the 12 items $(\alpha=$ 0.799) that constituted the tailored scale.

\section{Tax payment bias}

The construct; tax payment bias, was tested using 14 items $(\alpha=0.863)$. The items were structured on statistical scales employed by Devas, Delay \& Hubbard (2001) and Mourao (2006) and one of such items read as follows: "The tax collection system employed by this entity is very fair."

\section{Fiscal sabotage}

Fiscal sabotage as a predictor of public expenditure efficiency in local government was measured by an $(\alpha=0.824)$-based 14 item scale. The Dell'Anno \& Mourao (2012) adapted scale facilitated the items including: "[...] expenditure sabotage is openly apparent."

\section{Community sensitization}

As indicated earlier, community sensitization was a factor hypothesized to mediate the fiscal illusion-public expenditure efficiency relationship in local entities. Accordingly, a 15-item $(\alpha=0.881)$ modified scale adopted from related empirical works (Ferrari \& Manzi, 2014; Francis \& Robert, 2003), was employed to measure it.

One such item was: "The local community surrounding this entity fully appreciates its expenditure activities." In sum, the foregoing construct assessment identities largely suggest that their respective individual study variables hold internal consistence (reliability) levels $(0.65<\alpha<0.95)$ generally embraced by majority statistical circles (Cheung \& Lau, 2008; Gemmell, Morrissey \& Pinar, 2002; Hooper, Coughlan \& Mullen, 2008).

\section{Control variables}

According to past research (e.g. Cheung \& Lau, 2008; Clemens \& Miran, 2012; Ketchen, Boyd \& Bergh, 2008), participant biographic attributes potentially impair hypothesis test results. The effect can be minimized if they are controlled for (Clemens \& Miran, 2012; Ketchen, Boyd \& Bergh, 2008). Thus, in the current study, biographic characteristics: gender, age, marital status, educational level, position held, and tenure, were controlled for as follows: [Gender: $(0=$ female, $n=91 ; 1=$ male, $n=155)$ ]; [Age in years: $(1=20-30, n=37 ; 2=31-40, n=161 ; 3=41+, n=48)]$; [Marital status: $(1=$ single, $n=49$; $2=$ married, $n=157 ; 3=$ others $n=40)$ ]; [Educational level: $(1=$ certificate, $n=41 ; 2=$ diploma, $\mathrm{n}=52 ; 3=$ bachelor's degree,$+ \mathrm{n}=153)$ ]; [Job tenure in years: $(1=1-3, \mathrm{n}=69 ; 2=6-10, \mathrm{n}=150$; $3=7+, \mathrm{n}=27)]$.

Moreover, we also controlled for a latent factor formally adopted to augment the study instrument validity testing. Empirical convention (Edwards \& Lambert, 2007; Hooper, Coughlan \& Mullen, 2008) requires that such factors be subjected to a confirmatory factor analysis-based Harman's One Factor verification if validity is to be meaningfully established. However, given the factor's potential influence on hypothesis test results, it has to be controlled for accordingly (Hooper, Coughlan \& Mullen, 2008). 


\section{RESULTS AND DISCUSSION}

\section{Results}

The correlations alongside means (M) and standard deviations (SD) for the model variable and construct ratings are presented in Table 1. Generally, the ratings evidence moderate to strong positive inter-correlations. For instance: public expenditure efficiency has a positive and a moderate relationship with fiscal illusion $(r=.38, \mathrm{p}<.05)$ but relates more strongly with community sensitization $(\mathrm{r}=.45, \mathrm{p}<.01)$.

Table 1. Variable means (M), standard deviations (SD), reliability $(\alpha)$, and correlations

\begin{tabular}{|c|c|c|c|c|c|c|c|c|c|c|c|c|c|c|}
\hline \# & Item & $\mathbf{M}$ & SD & $\boldsymbol{\alpha}$ & 1 & 2 & 3 & 4 & 5 & 6 & 7 & 8 & 9 & 10 \\
\hline 1 & $\overline{F I}$ & 3.29 & 1.53 & .81 & 1 & & & & & & & & & \\
\hline 2 & PD & 2.99 & 1.54 & .79 & $.34^{* *}$ & & & & & & & & & \\
\hline 3 & ТРB & 3.11 & 1.51 & .88 & $-.19^{*}$ & $.23^{* *}$ & & & & & & & & \\
\hline 4 & FS & 3.00 & 1.56 & .83 & $.16^{*}$ & .34 & $.45^{* *}$ & & & & & & & \\
\hline 5 & FIL & 2.77 & 1.63 & .76 & $.23^{* *}$ & $.41^{* *}$ & -.31 & $.44^{* *}$ & & & & & & \\
\hline 6 & $\mathrm{CS}$ & 3.15 & 1.46 & .82 & $.37^{*}$ & -.22 & .18 & $.13^{*}$ & $.49^{*}$ & & & & & \\
\hline 7 & $\mathrm{TC}$ & 3.04 & 1.59 & .73 & $-.42^{*}$ & $.35^{*}$ & -.26 & -.31 & $-.27^{* *}$ & $.53^{* *}$ & & & & \\
\hline 8 & $\mathrm{RC}$ & 2.97 & 1.61 & .78 & -.34 & .19 & -.25 & $.33^{* *}$ & .46 & -.10 & $.28^{* *}$ & & & \\
\hline 9 & $\mathrm{PC}$ & 2.98 & 1.57 & .84 & .42 & $-.28^{*}$ & .51 & .21 & $.36^{* *}$ & $.15^{*}$ & .12 & $.40^{* *}$ & & \\
\hline 10 & PEE & 2.86 & 1.52 & .86 & $.27^{*}$ & $.35^{* *}$ & $.14^{* *}$ & $.26^{*}$ & $.38^{*}$ & $.45^{* *}$ & .32 & $.18^{* *}$ & $.38^{* *}$ & 1 \\
\hline
\end{tabular}

Notes: $\mathrm{n}=246$; FI=Fiscal Imbalances; PD=Political Divide; TPB=Tax Payment Bias; FS=Fiscal Sabotage; FIL=Fiscal Illusion; CS=Community Sensitization; TC=Technical Commitment; RC=Regulatory Compliance; $\mathrm{PC}=$ Projects Completion; $\mathrm{PEE}=$ Public Expenditure Efficiency; **Correlation is significant at the 0.01 level (2-tailed); *Correlation is significant at the 0.05 level (2-tailed); Study variables are in bold.

Besides, community sensitization relates with fiscal illusion to the extent of $(\mathrm{r}=$ $.49, \mathrm{p}<.01$ ). Such results are practically and empirically expected (see Afonso \& Fernandes, 2008; Mourao, 2006) given the misperception fiscal illusion creates to local communities in regard to entity spending mandates. This is confirmed by the technical commitment-fiscal illusion negative and significant association $(r=-.27, p<.01)$ suggesting how the fiscal illusion-rooted misperception impairs technical commitment (Gemmell, Morrissey \& Pinar, 2002).

A combination of hierarchical regression and structural equation modelling (path) analyses (Cheung \& Lau, 2008) was employed to test proposed hypotheses direct and mediation effects. Moreover, bootstrapping confidence interval (CI)-based analysis was engaged to reaffirm the SEM-generated mediation results (Cheung \& Lau, 2008; Hooper, Coughlan \& Mullen, 2008). All the said results are presented in Table 2.

As indicated earlier, Harman's One Factor analysis was performed to test the study instrument's construct and discriminate validity status. The collective validity stand obtains when Harman's indices compare badly with those of the measurement model (Edwards \& Lambert, 2007; Hooper, Coughlan \& Mullen, 2008). Indices for Harman's model were as follows: $(\chi 2=7.805 ; \mathrm{df}=11 ; \chi 2 / \mathrm{df}=0.710 ; \mathrm{IFI}=0.665 ; \mathrm{TLI}=0.741 ; \mathrm{CFI}$ $=0.893 ;$ RMSEA $=0.217$; L.046, H.134).

Those of the adopted five-factor measurement model were: $(\chi 2=15.856 ; \mathrm{df}=8 ; \chi 2 / \mathrm{df}=$ 1.982; IFI $=0.974 ;$ TLI $=0.991 ;$ CFI $=0.982 ;$ RMSEA $=0.028 ;$ L.000, H.104). Since the Harman model results compared badly to those of the measurement model, the situation implies strong instrument validity (Hooper, Coughlan \& Mullen, 2008).

The structural model indices required in verifying hypotheses direct and mediation effects were as follows: direct effect [Chi-Square $\left(\chi_{\mathrm{df}}^{2}\right)=.171 ; \mathrm{df}=1 ; \mathrm{p}=.679 ;(\chi 2 / \mathrm{df})=.171$; $\mathrm{GFI}=.991 ; \quad \mathrm{NFI}=.999 ; \quad \mathrm{RFI}=.988 ; \quad \mathrm{IFI}=1.004 ; \quad \mathrm{TLI}=1.064 ; \quad \mathrm{CFI}=1.000$; RMSEA=.026(L.127; H.760) at 90]; indirect effect [Chi-Square $\left(\chi^{2} \mathrm{df}\right)=.012 ; \mathrm{df}=1$; 
$\mathrm{p}=.912 ;(\chi 2 / \mathrm{df})=.012 ; \mathrm{GFI}=.989 ; \mathrm{NFI}=.991 ; \mathrm{RFI}=.999 ; \mathrm{IFI}=1.014 ; \mathrm{TLI}=1.044 ; \mathrm{CFI}=.998 ;$ RMSEA=.051(L.000; H.068) at 90].

Previous simulation research (e.g. Congleton, 2001; Gupta \& Marijn, 2001; Ketchen, Boyd \& Bergh, 2008) also commends such results as evidence of a robust structural model whose analysis has the potential of begetting reliable hypothesis test results.

As displayed in Table 2 , a positve and significant predictive relationship $(\beta=0.954, \mathrm{p}<$ .05 ) exists between fiscal imbalances and public expenditure efficiency. These results suggest data support to Hypothesis 1.

Similarly, the results for Hypothesis $2(\beta=0.621, \mathrm{p}<.01)$ indicate a positive and significant projective association between political divide and public expenditure efficiency. It had also been proposed as Hypothesis 3 that tax payment bias in surveyed local entities, predicts changes in public expenditure efficiency. The Table 2 results $(\beta=$ $0.734, \mathrm{p}<.05)$, also indicate data support for this empirical proposition. The last hypothesis direct effect proposal; Hypothesis 4, was that fiscal sabotage explains public expenditure efficiency in such jurisdictions. Statistical findings $(\beta=0.848, p<.05)$, signify a positive and significant fiscal sabotage-expenditure efficiency linkage suggesting related data backing.

Table 2. Hypotheses analysis

\begin{tabular}{|c|c|c|c|c|c|}
\hline \multicolumn{6}{|l|}{ Dependent Variable: Public Expenditure Efficiency } \\
\hline Particulars & $\beta$ & SE & $\mathrm{t}$ & TV & VIF \\
\hline \multicolumn{6}{|l|}{ Direct Effects } \\
\hline Fiscal Imbalances $\rightarrow$ Public Expenditure Efficiency & $.954^{*}$ & .36 & 2.64 & .62 & 1.64 \\
\hline Political Divide $\rightarrow$ Public Expenditure Efficiency & $.621^{* *}$ & .29 & 1.89 & .68 & 3.48 \\
\hline Tax Payment Bias $\rightarrow$ Public Expenditure Efficeincy & $.734^{*}$ & .81 & 1.53 & .45 & 2.31 \\
\hline Fiscal Sabotage $\rightarrow$ Public Expenditure Efficiency & $.848^{*}$ & .53 & 2.17 & .53 & 4.03 \\
\hline Indirect Effect & & & & & \\
\hline $\begin{array}{l}\text { Fiscal Illusion } \rightarrow \text { Community Sensitization } \rightarrow \text { Public Exp. Efficiency } \\
\text { Adjusted } R^{2}[.718]\end{array}$ & -.538 & 47 & 2.24 & .37 & 3.06 \\
\hline Bootstrapping Results: Indirect Effect (CI) [-0.093↔0.035] & & & & & \\
\hline
\end{tabular}

Most critically, however, it had been projected as Hypothesis 5, that community sensitization mediates the fiscal illusion-public expenditure efficiency relationship in local government. The convetional structural equation modeling (Edwards \& Lambert, 2007; Hooper, Coughlan \& Mullen, 2008); Table 2 hypothesis indirect effect analysis results $(\beta=-0.538, \mathrm{~ns})$, suggest a negative and non-significant community sensitization mediation effect to that relationship. This implies that data from surveyed Ugandan-based entities could not support that hypothesis. Conversely, some scholars; notably Cheung and Lau (2008), hold reservations on the authenticity of regular SEM-based hypothesized indirect effect outcome. The two researchers argue that much as SEM is admittedly a robust simulation test technique, its mediation results are often compromised by structural model defects.

Accordingly, the current study's community sensitization factor was therefore subjected to further mediation verification: bootstrap testing (Cheung \& Lau, 2008). Also rooted in the AMOS-SEM package, bootstrapping is globally perceived a more in-depth indirect effect testing technique by several statistical analysts (Cheung \& Lau, 2008; Clemens \& Miran, 2012). 
On the basis of 2000 micro-samples, the $95 \%$ bias-corrected bootstrap employed in this study, produced a zero-content confidence interval (CI) of [-0.093 $\leftrightarrow 0.035]$. According to Cheung \& Lau (2008), the moment a bootstrap CI or range holds a zero value within it; it is a full confirmation that a mediation influence does not exist.

The current study's statistical results: correlation, regression, structural equation modeling, and bootstrapping, are deemed quite reliable given its robust data structure. Notably, the dataset's common methods variance and multi-collinearity threats are very minimal. As shown in previous research (e.g. Blair, 2000; Edwards \& Lambert, 2007; Ketchen, Boyd \& Bergh, 2008; Mourao, 2006), data with tolerance values (TV) $(\leq 1.00)$ and variable inflation factors $(\mathrm{VIF})(\leq 10.00)$ are considered generally safe from the multi-collinearity threat. The study TV and VIF values presented in Table 2 meet these standards.

\section{Discussion}

The ensuing discussion of the present study's findings is undertaken variously from the context of contemporary theoretical, empirical, and practice environments. It is also important to note that; much as majority findings corroborate previous literature, several of them introduce quite innovative ideas to the local government expenditure efficiency knowledge body.

For instance, it had been proposed as Hypothesis 1 that fiscal imbalances relate positively with public expenditure efficiency in local government. Data generated from surveyed entities in northern Uganda supported that hypothesis. Moreover, this finding is in congruence with earlier empirical evidence in the work of Dollery \& Worthington (1996). Recently Dell'Anno \& Mourao (2012) also assert that fiscal imbalances explain changes in expenditure efficiency in such localities.

Consistent with the fiscal illusion theory (Oates, 1991; Wagner, 1976), local entities should institute measures that can mitigate fiscal illusion-related misperception often responsible for spending inefficiency. Dell'Anno \& Mourao (2012) suggest independent judicial systems, partisan politics maturity, and fiscal transparency as notable measures for Sub-Saharan Africa localities.

In Hypothesis 2, it had been anticipated political divide and public expenditure efficiency also have positive linkages. Oates (1991) posits in the fiscal illusion theory that the moment local jurisdictions operate in divided political environments; their expenditure efficiency measures will always be compromised.

This enforces the Wagner (1976) and recent research (e.g. Dell'Anno \& Mourao, 2012; Gemmell, Morrissey \& Pinar, 2002; Guziejewska, 2016) observation that it is politics that determines local spending mandates especially in resource-strained economies of the developing world.

Thus, any flaws in the political machinery seriously undermine expenditure goals (Gemmell, Morrissey \& Pinar, 2002; Guziejewska, 2016). Ugandan-based local governments are a living example as victims of the foregoing political divide-public expenditure efficiency triangulation (Dell'Anno \& Mourao, 2012; Gemmell, Morrissey \& Pinar, 2002). Past studies; notably (Congleton, 2001; Devas, Delay \& Hubbard, 2001; Dollery \& Worthington, 1996; Gemmell, Morrissey \& Pinar, 2002), provide empirical evidence that: tax payment bias significantly affects public expenditure efficiency in local government. 
Moreover, according to Oates (1991)'s fiscal illusion theoretical perspective, local spending proficiency is a function of balanced tax payment systems. This research had predicted particularly in its Hypothesis 3, that tax payment bias has a positive bearing to public expenditure efficiency in local entities.

Thus, the practical implication for local authorities in Africa; Uganda's entities inclusive, is that realistic and stable tax systems are inevitable for expenditure efficiency.

Conventional logic, theory, and empirical evidence (e.g. Clemens \& Miran, 2012; Dollery \& Worthington, 1996; Guziejewska, 2016) categorically indicate that fiscal sabotage must be responsible for public expenditure inefficiency in local jurisdictions. As stated in the present study's Hypothesis 4, fiscal sabotage indeed associates positively with public expenditure efficiency.

Both Oates (1991) and Wagner (1976) cautioned public entities on the potential risks fiscal sabotage pose to spending endeavors and as confirmed practically, several Sub-Saharan African entities have fallen victims. Ethiopia, Ghana, Nigeria, South Africa, and Uganda; to name but a few African countries, frequently acknowledge politicalrelated fiscal sabotage. The practice has tremendously undermined their fiscal federalism systems but especially local spending efficiency (Dollery \& Worthington, 1996; Guziejewska, 2016).

Finally, it had been postulated in Hypothesis 5 of this research that in local entities, community sensitization mediates the relationship between fiscal illusion and public expenditure efficiency. Contrary to past empirical stand, notably: Ferrari \& Manzi (2014), and Francis \& Robert (2003), data did not render support to the hypothesis test results. Such findings may arise in post-conflict traumatized societies such as that of northern Uganda in which this study was conducted. Driven by fiscal illusion misperception (Clemens \& Miran, 2012; Guziejewska, 2016; Oates, 1991) typical of resourceconstrained African entities, traumatized communities may find it a challenge to appreciate public spending efficiency sensitization benefits.

\section{CONCLUSION AND RECOMMENDATIONS}

\section{Conclusion}

Possibly, this study is one of the very first efforts to address the issue of local entity public expenditure efficiency from a fiscal illusion theoretical perspective and particularly in a post-conflict environment of Sub-Saharan Africa. Previous research (e.g. Blair, 2000; Clemens \& Miran, 2012; Dollery \& Worthington, 1996), has largely neglected the matter especially when it obtains in a post-war setting. Its findings are therefore considered a significant contribution to the existant literature.

Moreover, when theorizing expenditure efficiency in such entities, past scholars (Afonso \& Fernandes, 2008; Dell'Anno \& Mourao, 2012) often highlight the importance of fiscal illusion-related misperceptions. The apparent influence of community sensitization on fiscal illusion-expenditure efficiency linkages is always downplayed except in few studies (Ferrari \& Manzi, 2014; Francis \& Robert, 2003).

Thus, this research impacts theory by critically examining how fiscal illusion theoretical underpinnings relate to fiscal illusion-community sensitization-expenditure efficiency relationships. Besides, it evaluates that theoretical influence in a post-conflict environment of resource-strapped economies of the developing world.

In terms of implication to practice, this study suggests that local government authorities must always be conversant with the role fiscal illusion plays in the expenditure 
efficiency equation. As rightly observed by Gemmell, Morrissey \& Pinar (2002), Gupta \& Marijn (2001), and Mourao (2006), understanding the fiscal illusion dynamics is a key task for entity administrators, employees, and political representatives in executing spending mandates effectively.

Furthermore, entity leadership whether in conflict-ridden environs or not, should never ignore the relevancy of community sensitization in attaining expenditure efficiency. The sensitization factor is often sidelined due to associated trauma contrary to previous empirical evidence (e.g. Ferrari \& Manzi, 2014).

In conclusion, this research takes a step in creating understandability of the fiscal illusion-community sensitization-public expenditure efficiency connections in local government. While the situation may be different in the developed world, local entity expenditure efficiency in poor and developing nations such as those of Sub-Saharan Africa seems to be a big challenge. In Uganda's post-conflict northern region, attaining acclaimed expenditure efficiency standards is yet to be seen.

\section{Recommendations}

Generally the study findings highlight the expected causal linkage in the fiscal illusion-community sensitization-public expenditure efficiency framework predicted by the fiscal illusion theory. However, we did not investigate the reigning inter-variable causality in its fullness. As indicated in related studies (Clemens \& Miran, 2012; Congleton, 2001; Devas, Delay \& Hubbard, 2001), three alternative research designs are proposed to strengthen causality evidence.

First, a longitudinal research design capable of capturing pre-conflict data. This can; for instance, facilitate more effective investigation of community sensitization as an actual mediator factor. However, identifying proper units of analysis prior to conflict may be a challenge due to forecast unpredictability (Congleton, 2001; Devas, Delay \& Hubbard, 2001).

Second, an experimental design could potentially isolate all causal effects. But as noted Clemens \& Miran (2012), conducting experimental research in natural and largely rural-based locality settings of Africa, may be very problematic. Besides, such a research design is likely to suffer common methods variance, multicollinearity, and validity setbacks (Ketchen, Boyd \& Bergh, 2008).

Third, a systematic research agenda is also proposed. According to Congleton (2001), the approach involves collecting both respondent observational data on a longitudinal basis and back-up documentary evidence. However, such a strategy may be compromised by post-conflict trauma conditions if executed in a setting like that of northern Uganda.

The present study presents a number of findings in regard to local entity fiscal illusion-community sensitization-public expenditure efficiency triangulation. However, several of the findings require further research. One potential explanation for attaining meaningful expenditure efficiency was that fiscal illusion be addressed at local level. If this position is maintained, then the role of central government would be overlooked.

On the basis of fiscal illusion theory (Oates, 1991; Wagner, 1976) and any other related theory, it is therefore important for upcoming research to equally consider the central authority influence in the expenditure efficiency endeavors of its local governments. Additionally, future research should investigate community sensitization mediation in the fiscal illusion-public expenditure efficiency relationship in regular and 
non-post-conflict entity settings. Comparative findings (Clemens \& Miran, 2012; Ferrari \& Manzi, 2014; Gupta \& Marijn, 2001) will significantly enrich the local expenditure efficiency knowledge body and enhance the broad fiscal federalism stream.

\section{REFERENCES}

Afonso, A. \& Fernandes, S. 2008. Assessing and explaining the relative efficiency of local government. Journal of Social Economics, 37, 1946-1979.

Blair, H. 2000. Participation and accountability at the periphery: Democratic local governance in six countries. World Development, 28(1), 21-39.

Cheung, G.W. \& Lau, R.S. 2008. Testing mediation and suppression effects of latent variables: Bootstrapping with structural equation models. Organizational Research Methods, 11, 296-325.

Clemens, J. \& Miran, S. 2012. Fiscal policy multipliers on sub-national government spending. American Economic Journal: Economic Policy 4(2), 46-68.

Congleton, R. D. 2001. Rational ignorance, rational voter expectations, and public policy: A discrete informational foundation for fiscal illusion. Public Choice, 107(1), 3564.

Dell'Anno, R. \& Mourao, P. 2012. Fiscal illusion around the world: An analysis using structural equation modeling approach. Public Finance Review, 40(2), 270-299.

Devas, N., Delay, S. \& Hubbard, M. 2001. Revenue authorities: Are they the right vehicle for improved tax administration? Public Administration and Development, 21, 211222.

Dollery, B. \& Worthington, A. 1996. The empirical analysis of fiscal illusion. Journal of Economic Surveys, 10, 261-297.

Edwards, J. R. \& Lambert, L. S. 2007. Methods for integrating moderation an mediation: A general analytical framework using moderated path analysis. Psychological Methods, 12(1), 1-22.

Ferrari, P. A. \& Manzi, G. 2014. Citizens evaluate public services: A critical overview of statistical methods for analyzing user satisfaction. Journal of Economic Policy Reform, 17, 236-252.

Francis, P. \& Robert, J. 2003. Balancing rural poverty reduction and citizen participation: The contradictions of Uganda's decentralization program. World Development, 31(2), 325-337.

Gemmell, N., Morrissey, O. \& Pinar, A. 2002. Fiscal illusion and political accountability: Theory and evidence from two local tax regimes in Britain. Public Choice, 110(34), 199-224.

Gupta, S. \& Marijn, V. 2001. The efficiency of government expenditure: Experiences from Africa. Journal of Policy Modeling, 23, 433-467.

Guziejewska, B. (2016). Theoretical dimensions of fiscal illusions in local government finance. Journal of Economics, Business and Management, 4(3), 215-219.

Hooper, D., Coughlan, J. \& Mullen, M. 2008. Structural equation modeling: Guidelines for determining model fit. Electronic Journal of Business Research Methods, 6, 1, 53-60.

Ketchen, D. J., Boyd, B. K. \& Bergh, D. D. 2008. Research methodology in strategic Management: Past accomplishments and future challenges. Organizational Research Methods, 11, 643-658. 
Mourao, P. 2006. The economics of illusion: A discussion based on fiscal illusion. Journal of Public Finance and Public Choice, 25(1), 96- 115.

Oates, W. 1991. On the nature and measurement of fiscal illusion: A survey. In Oates, W. Ed. Studies in Fiscal Federalism, Brookfield, VT, Edward Elgar.

Wagner, R. 1976. Revenue structure, fiscal illusion, and budgetary Choice. Public Choice, 25, 45-61.

(C) 2020 by the authors. Licensee JPPD, Indonesia. This article is an open access article distributed under the terms and conditions of the Creative Commons Attribution (CC BY) license (http://creativecommons.org/licenses/by/4.0/). 